Historic, archived document

Do not assume content reflects current scientific knowledge, policies, or practices. 



\subsection{7}
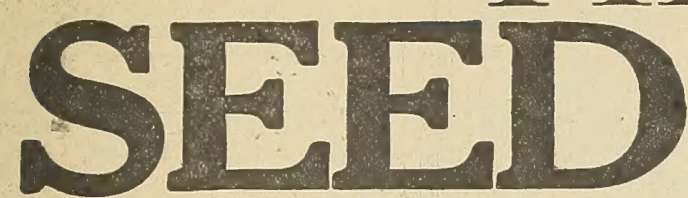

Printed and Published in the Private Printshop of the Henry Field Seed

Company,

Shenandoah, Iowa
Shenandoah, Iowa, April, 1923

\section{Planting Dahlias}

The essential things for good blooms are good tubers, planted at the right time, thorough cultivation of the soil at all times, never allowing a crust to form on the ground and no weeds to grow; deep cultivation at first and shallow after blooms appear, but never stop cultivating if you want the best.

Plant 5 to 6 inches deep in medium rich soil $3 \mathrm{ft}$. apart; use no fresh $\mathrm{ma}$ nure or fertilizer until buds appear, then only as a mulch or raked in the top soil. Dig after frost, and store in a dry, cool, frost-proof cellar, same as Irish potatoes.

\section{Color Collection}

12 Dahlias for $\$ 1.75$

Twelve choice Dahlias in assorted colors, no two alike, all good strong tubers, well packed in a box, and mailed postpaid for $\$ 1.75$. Our selection from varieties listed further on. Colors marked separately. Money back if not suited.

\section{Mixed Dahlias}

We have quite a lot of mixed dahlias, all colors and kinds, which we will sell cheap. They are mostly double. Cannot promise any special colors. They are good, sound bulbs, all good bloom. ers and a bargain at the price. 6 for $65 \mathrm{c}, 12$ for $\$ 1.25$, all postpaid.

\section{Named Sorts of Dahlias}

In our big catalog which you already have, you will find a complete list of the best named sorts of dahlias in every type and color. Look them up. They are not expensive and I know you wlil enjoy growing them. We send out only good strong roots with buds showing. There is no room here to print the entire list, but we can suit with any color or style you want. Or, if you wish to leave the selection to us, you will find the collections above good ones. We have all the bulbs in stock and can make prompt shipment.

\section{Exhibition Color Collection}

This collection is made of twelve types and colors of the most popular Dahlias of later introduction-just the finer ones. 6 for $\$ 1.50 ; 12$ for $\$ 3.00$. See big catalog for named sorts. 


\section{A Beautiful Pink Canna}

For years we have been hunting for a really worth-while pink Canna, and we have at last found it in Miss Florence Hall. It originated with a customer of ours in Arkansas, and we got a few of them for trial last summer. They proved so fine that we aimed to keep all the roots for our own planting this summer, but we succeeded in getting an additional supply from the originator.

Description. It is a deep rose pink in color, of the most beautiful shade imaginable. The flowers are very large in size, and borne in immense compact clusters. It is a very free bloomer, beginning to bloom when quite small. It is hardy and the roots keep well. The foliage is dark green, and the plants grow 3 to 5 feet high, according to soil and season. I consider it the best canna we have ever grown, and it has the additional value of the rare rose pink color.

Price-Started roots, $65 \mathrm{c}$ each, 2 for $\$ 1.15,6$ for $\$ 3.00$, all postpaid.

\section{Special Canna Offer-The 3 Best for $\$ 1.00$}

There are two other cannas good enough to go with this one, and I am mak Ing a special offer on the three. They are Miss Florence Hall (described above), The Preaident, which is the best deep red, and Lemon Yellow, which is the best yellow. All have dark green leaves, compact growth, and enormous clusters of large flowers. All grow about the same height, 3 to 5 feet. If you want to get a start of the three best Cannas grown, this is your chance.

Price-Special Offer, one each of these three, for $\$ 1.00$ postpaid.

\section{Caladiums and Dasheens}

These two plants are very similar and I doubt if you could tell them apart. They are fine to use as ornamental plants, either to stand alone or as a border for taller plants. They are especially fine as a border for Canna beds. Plant the bulbs about 2 feet apart in the row, if used as a border.

The bulbs are quite large, sometimes as large as 3 inches in diameter. The leaves are very large, wide, and long, and their peculiar appearance gives the plant the common name of "Elephant Ear." Bulbs grow easily and are quite cheap.

PRICES-Caladium, large size, $15 \mathrm{c}$ each, 2 for $25 \mathrm{c}, 12$ for $\$ 1.40$

Dasheens, small, $7 \mathrm{c}$ each, or $65 \mathrm{c}$ per dozen.

Dasheens, large, $10 c$ each, or $\$ 1.00$ per dozen.

\section{Still Time to Plant Dahlias}

There is plenty of time yet to plant dahlias, in fact, they seem to do best planted late, say in May or June. I have planted as late as July 4th with good results. I can supply mixed colors, unnamed, at $\$ 1.25$ per dozen, postpaid. Also a very fine collection of 12 named sorts, no two alike, for $\$ 1.75$ postpaid.

Dahlias can also be grown from seed. We sell it at $10 \mathrm{c}$ per packet. Plant and tend just like tomatoes. They bloom the first year, but mostly singly.

\section{Hardy Lillies}

Lemon Lily. (Hemerocallis). A very fragrant, hardy old-fashioned flower. It blooms in May very freely, in clusters, on slender stems about 2 feet high.

Day Lily. (Hemerocallis Fulva). Much like the lemon lily except darker in color and taller. Blooms in July and August. $20 \mathrm{c}$ each, or $\$ 2.00$ per dozen.

Tiger Lily. (Lillium Tigrinum). A deep orange red, with black spots. Very showy and hardy. Price 25c.

Most of us think of flowers as a source of pleasure only, but there is a real chance for profit in growing them, and it is getting to be a better proposition every year.

Many women who are looking for a chance to make some money for themselves are overlooking a good opportunity in not trying flowers.

The easiest for the ordinary person to grow and the most practical and most likely to succeed, would be the Gladiolus. They will grow anywhere in the U. S. in any climate and on any soil.

They are free of insect or disease troubles, need only ordinary good garden care and make a crop of both blooms and bulbs, both of which are readily saleable.

The picture above taken in my garden wi'? show you how fine they look in bloom. They come in ail colors and shades, and bloom all through July, August and September, with a few early ones in June. Each bulb makes from one to three of these beautiful spikes of bloom, which sell at from $5 c$ to $50 c$ each according to the season and the market. Then in the fall you can dig the bulbs and sell them. They increase rapidly.

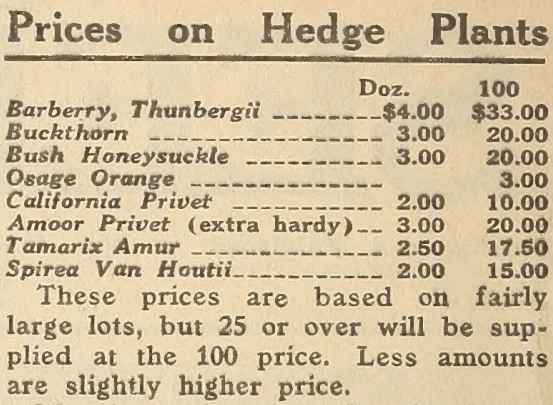

slightly higher price.

We do not prepay the charges at these prices. They are based on the plants going by express at your expense. W pack in good shape without extra charge, and guarantee delivery by express.

It is best to figure on setting the plants one foot apart in the row to make a good hedge, so order as many as you have feet of hedge to plant.

All plants are field grown, thrifty and healthy, and at least two years old. They are selected for uniform height so they will make a nice hedge.

\section{Small Hedging Plants}

The prices quoted for various plants or hedges on the upper part of this page are for good large plants at least 2 years old. Many people, however, would just as soon have smaller plants at the difference in price. So if you can use smaller, younger plants, we can supply them at two-thirds of above prices.

\section{Extra Large Hedging}

(I especially advise the Amoor Privet)

There are usually some folks who want a hedge in a hurry and are willing to pay more for extra large stock. We grew quite a bit of hedging here on our grounds this season and have some exceptionally good large stock to offer at one-half more than the regular price. This includes California Privet, Amoor River Privet, and Spirea Van Houtii. Be sure to mention on your order that you want the extra large stock.

Fortunately, they are not expensive to buy. I am giving here a list of special prices we are making on some of the very best sorts, ones that I would advise you to grow.

\section{Special Prices Blooming size Bulblets}

Fields Finest Mixed, all colors_.. $\$ 2.50$ \$ 25

Primulinus Hybrids, bright yellow - $\quad 3.50 \quad .35$

Niagara, soft creamy yellow _.... $\quad 5.00 \quad .50$

Ida $V$ an, a fine big red $\quad 3.50$

Meadowvale, almost pure white_-- $\quad 5.00 \quad 50$

Mrs. Frances King, large tall red_ $\quad 3.50 \quad .35$

America, standard pink varitey_... $\quad 3.50 \quad 35$

Halley, large orange rose, early_-. $\quad 3.50 \quad .35$

Helen Franklin, a ruffled pure white 15.00

Prince Of Wales, coral pink, early 10.00

$\begin{array}{lll}\text { Gretchen Zang, pink and scarlet__. } & 8.00 & 80\end{array}$

Mary Fennell, soft lilac color_... $10.00 \quad 1.00$

Le Marechal Foch, great new pink 12.00 , 1.00

Not less than 30 bulbs of a kind, nor 100 bulblets of a kind at these special prices. All prices are postpaid. Full directions with orders. Bublets will grow in one year to blooming size. Field's Finest Mixed bublets, $\$ 1$ per 1,000. 


\section{A Tribute}

My father, Hon. S. E. Field, passed away March 6, 1923, aged almost 89 years. You could hardly say he was ill, for he was busy and cheerful as usual almost to the last. He simply got through and passed on.

It has always seemed to me that the keynote of my father's life and character was his genial friendliness. I have known a great many men in my time and $I$ doubt if $I$ ever knew a man who was so genuinely friendly and genial and pleasant with everyone, as my father, Sol Field.

And, too, it has seemed to me that he came nearer to real success than most men. Not that he was rich, for the Fields are seldom rich and seldom poor, and he was a typical Field. But he always had enough for comfort, and he lived a long, happy, helpful and contented life. And what more could any one ask?

We children were taught, not so much by words as by his own example, that it was a disgrace to be lazy, discourteous, grouchy or tricky. It was taken for granted that if we were to hold up our heads as Fields, we must be busy, courteous, honest, pleasant and helpful. And whatever we children have been and have achieved has been due almost entirely to these principles taught us by our father.

And he set an example, not only for we children but for the whole community. In company with a group of other early settlers of the same type, he helped to crystallize the spirit of the town and make it the friendly, busy, clean town it has always been.

I sometimes wonder if we younger men are living up to the high mark set for us by these pioneers.

His busy life really spanned the continent, and the greater part of a century. Born in Franklin county, Mass., July 8, 1834 , he came as a young man to central Illinois when that country was considered the far West. Twenty years in Illinois, made up of teaching, farming, service in the Civil War, and he moved to Iowa, where after 40 years on one farm near Shenandoah, he went on west to California, where he lived until my mother's death about four years ago. Eince then he has made his home part of the time in California and part here

But wherever he went and wherever he lived, he was the same busy, helpful, pleasant, contented and clean man Always interesting and always interested.

And wherever he went he was always surrounded with flowers and garden and fruit and happy children. They all seemed a part of his life.

And I believe that when my own time comes to go, the highest compliment that can be paid my memory will be if they can say truthfully, "Well, he was a whole lot like his father."

Henry Field.

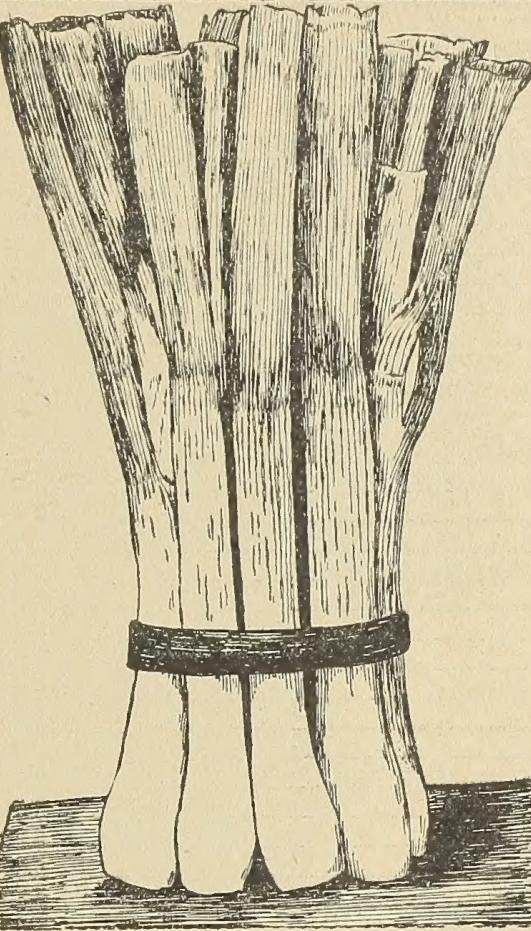

Bunch Onions Grown from Sets

\section{Growing Onions From Sets}

The quickest, easiest and surest way to grow a crop of onions is from bottom sets planted very early in the spring They are more expensive than the seed but take less weeding and come in much earlier. They should be planted in rows anywhere from 1 to 3 feet apart in the rows, about 3 inches deep and carefully set, right end up

It will take anywhere from 300 to 1,000 pounds per acre of the sets, say 9 to 30 bushels, according to how thick they are planted. They can be pulled and sold green for bunch onions, or allowed to ripen down for big, dry onion for fall and winter sale. The best sets should be small, sound, dry, un sprouted, not over an inch and not less than one-fourth inch in diameter. Our bottom grown sets are especially fine.

These sets are generally sold by the pound, and run all the way from 100 to 500 to the pound, according to size. When sold by the bushel they are counted at 32 pounds to the bushel. They can be had in either red, white or yellow.

\section{Postpaid Prices Onion Sets}

(Either red, yellow or white)

$1 / 2$ ib, 15c; tb, 25c; 3 tb s, 65c

Postpaid Quantity Prices Gal. Peck Zone 2 _. Zone $3 \ldots \ldots \ldots$. 1.24 Zone 4 _. 88

Zone 5 _.............. .97

Zone 6 _. 1.06

1.81

Prizetaker and Mountain

\section{Danver Sets}

If you want to grow a crop of big mild onions, plant Prizetaker and Mountain Danvers sets. They are just as good for green or bunch onions as the regular bottom sets and better for large onions, but their chief value lies in the fact that they will grow a big onion so much quicker than from seed. And you know the early market on big onions is worth getting after.

Instead of paying a fancy price to the grocer early in the season for those big yellow onions that come in crated up, grow your own. You can do it just as well as not by planting either of these varieties. We have a car of each this season and when they are gone we will have to return your money or give you something else. So better order early or if you can't do this, make a second choice. Price postpaid $30 \mathrm{c}$ per lb. or 3 pounds for $75 c$.

Portpaid Quantity Prices Gal. Peck

Zone 2

Zone 3._.

Zone 4 (n) 1.53

Zone 5 _ 1.72

Zone 6 6 - 1.161 .91

\section{Growing Late Cabbage}

There is always a demand for late cabbage, and many people fail because they cling to the idea that the plants must be started in a hot bed or cold frame and transplanted to the field also that it must be started rather early.

Plant the seed right in the field where you want your crop to grow. Use a pound of seed to the acre. That is more than you will need if you trans. plant, but, nevertheless, it is cheaper by the time you pay for labor of trans. planting and risk of losing your crop by dry weather or a poor start.

Don't get your crop in too early. In this latitude, southern Iowa, plant seed for your late crop the last of May. If planted too early, the worms will get it, and it will ripen too early to store.

Cabbage will yield up to 25 tons per acre. The prices retail up to $5 \mathrm{c}$ per $\mathbf{l b}$. Figure $121 / 2$ tons, which is reasonable, and an average of $3 c$ per pound in quantities. That figures gross returns at $\$ 506.00$ per acre, out of which you should deduct say three or four dollars for seed and the cost of your labor.

\section{Good Luck With Hogs}

"A few lines about the two sows I bought in your ale March 14, 1922. I sure raised some good pigs out of them, 6 boars and 7 sows. They sure did fine for me. They outgrew my other hogs 125 to 150 pounds, the same age and the same feed. I had them to two county fairs and got 14 ribbons with them, which was not so bad, and I sold the boars for $\$ 180.00$. The two sows cost me $\$ 177.50$. Had the 7 young sows and the 2 old sows left. Spots for me. Yours truly,? 


\section{The Winners in the February "Country Printer" Puzzle}

1 Wm. Richard Gale, Turner, Oregon _.... $\$ 650.00$

2 Mrs. Cecil M. Cole, East Canon City, Colo, Rt. 2 .

250.00

3 A. F. Holt, 1819 First St., N. W., Washington, D. C.

4 Mrs. P. A Olson, So. Peck St., Fergus Falls, Minn.

5 Mamie Caudle, Stacy, Calif.

6 Foss O. Heaton, Shannon City, Iowa.

7 Will R. Kubley, Rt. 1, Tiosa, Ind..

8 Charles H. Essig, Rt. 2, Argos, Ind.

9 C. C. Raymond, Flannigan, Nev..

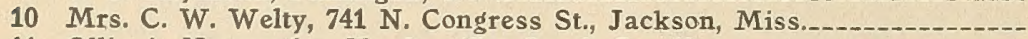

11 Ollie A. Nosworthy, Hardeeville, South Carolina

12 F. A. Bowman, Tompkinsville, Ky.

13 Mrs. Walter W. Waring, Hamilton, Kans.

14 John E. Groves, 1800 Harrison St., Chicago, Ill.

15 C. Mach, Whitman, Nebr.

16 Mrs. Elizabeth Dyer, Rt. K, Lafayette, Ind.

17 Mrs. Ella A. Stinman, Box 283, Callaway, Nebr.

18 Thalia Nelson, Dundas, Minn.

19 Carl A. Crouse, Liscomb, Iowa

20 W. E. Gossard, Webster City, Iowa

21 Mrs. Geo. C. Fitch, Sherwood, North Dakota

22 Albert Thompson, Dundas, Minn.

23 Sampel P. Beard, Carlock, Ill.

24 Mrs. P. H. Butler, 33rd and Granby St., Norfolk, Va.

25 Mrs. Allen Henry, Oskaloosa, Iowa.

26 Claude A. Barr, Smithwick, South Dakota

27 J. B. McAndrew, Box 399, Boulder, Colo.

28 Lillie M. Swope, Rt. 1, Des Moines, Iowa.

29 Edward Perdue, Huron, Kans.

30 Chas. A. Whipple, Greenfield, Iowa

125.00

75.00

25.00

15.00

15.00

15.00

5.00

1.00

5.00

5.00

5.00

5.00

5.00
2.00

5.00

5.00
5.00

5.00

5.00

5.00

5.00
5.00

5.00

Our customers all had a lot of fun with the "country printer" puzzle which we run in January and February. The judges had a hard siege with the answers, for there were so many of them and so good, but they finally got through the last part of March, and turned the list of winners over to us as above, and we have mailed checks as specified.

An interesting phase of it was that the winners won out by the use of the very largest, longest words they could find, rather than a greater number of words. They dug up words that I never knew were in the dictionary, but when we looked them up they were there all right.

The winners are all strangers to me. Never met a one of them. Hope they spend the money wisely. A copy of the winning list will be sent on request to any one interested.

\section{The Winner}

Wm. Richard Gale, Turner, Oregon, won first prize with a score of 6231. We got his $\$ 5.00$ on the 15 th of January, so his check is for $\$ 650.00$. Some of his words look silly, but every one of them is in Webster's dictionary, in exactly the form he uses. None of them are obsolete, compound, or otherwise objectionable.

As soon as the judges told us who got the first prize, we wired him the good news and asked him to wire us at once, who he was, how old he was, what he was going to do with the money, and everything else that would be of interest to our Seed Sense folks. Here is his answer:

"I am overjoyed at the good news in your telegram received this morning. I take care of dairy cows, doing Register of Merit test work. I was born in Connecticut in 1900. We will use some of the contest money to help on our farm payment, and maybe we will get to take a trip back to Connecticut this summer.

\section{Our New Puzzle is Easier:}

Our new puzzle, which closes May 15, is much simpler and easier and has a much greater number of prizes, and there is no reason why every one should not have a try at it anyway. You need seeds and flower plants and all such stuff, and you can just as well buy them of us as any one else, and have a try at the puzzle at the same time. Or you can try the puzzle without buying anything, if you wish. You probably have a copy of the new puzzle, or if not there will probably be a copy of it in this Seed Sense. Look it over.

\section{What the Customers Say About Our Puzzles}

Most of our customers think they get their money's worth whether they win a prize or not. Here's what one says:

"Such contests are splendid auxiliaries to other education, particularly to common school education. I study such puzzles as a matter of further word education and I find such studies not only deeply interesting but very beneficial in adding to my vocabulary." - Walt LeNoir Church, Long Beach, California.

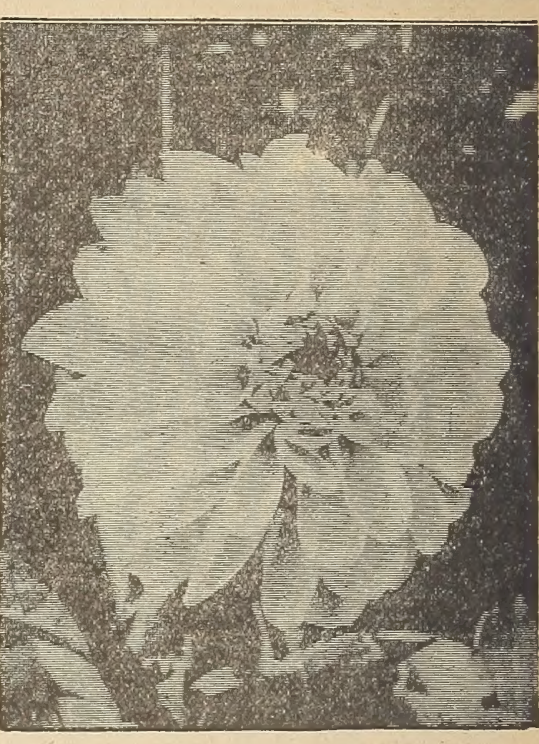

\section{Growing Dahlias From Seed}

Few people realize that dahlias can be grown so easily and cheaply and quickly from seed.

The seed should be started early in the spring, like growing tomato or cabbage plants. Of course you can plant the seed right in the open if you want to, and they will, with good care, bloom before fall, but if you handle them like early tomatoes, they will come into bloom much nicer.

You will get all colors, and all shapes, some not much account, and some fine, but all interesting. You can save bulbs from the best ones for next year. Prices, finest mixed seed, pkt. $10 c$, 3 pkts. 25c.

\section{Pansy Plants for Sale}

We will have thousands of pansy plants for shipment after April 15th. They are grown from the finest strain of seed and we can assure all lovers of this beautiful flower that they will be surprised and pleased with the size and beauty of this strain of pansies. They will be sent by mail, extra well packed, and safe arrival guaranteed. 1 dozen, mixed colors, postpaid_\$ .75 3 dozen, mixed colors, postpaid_ 2.00

\section{Aster Plants}

We will have some nice Aster plants to offer in April and May at $40 \mathrm{c}$ per doz. for mixed. or $50 \mathrm{c}$ ver doz. for separate colors. These will be good strong, transplanted plants, and will be mailed postpaid.

\section{Other Flower Plants}

Salvia, or Scarlet Sage___\$1.00 doz. Verbenas, mixed colors... $\$ 1.00$ doz. Moonvines, white Geraniums, red for beds_- $\$ 2.40$ doz. Postpaid, or if wanted with dirt on roots, by express at your expenso. 


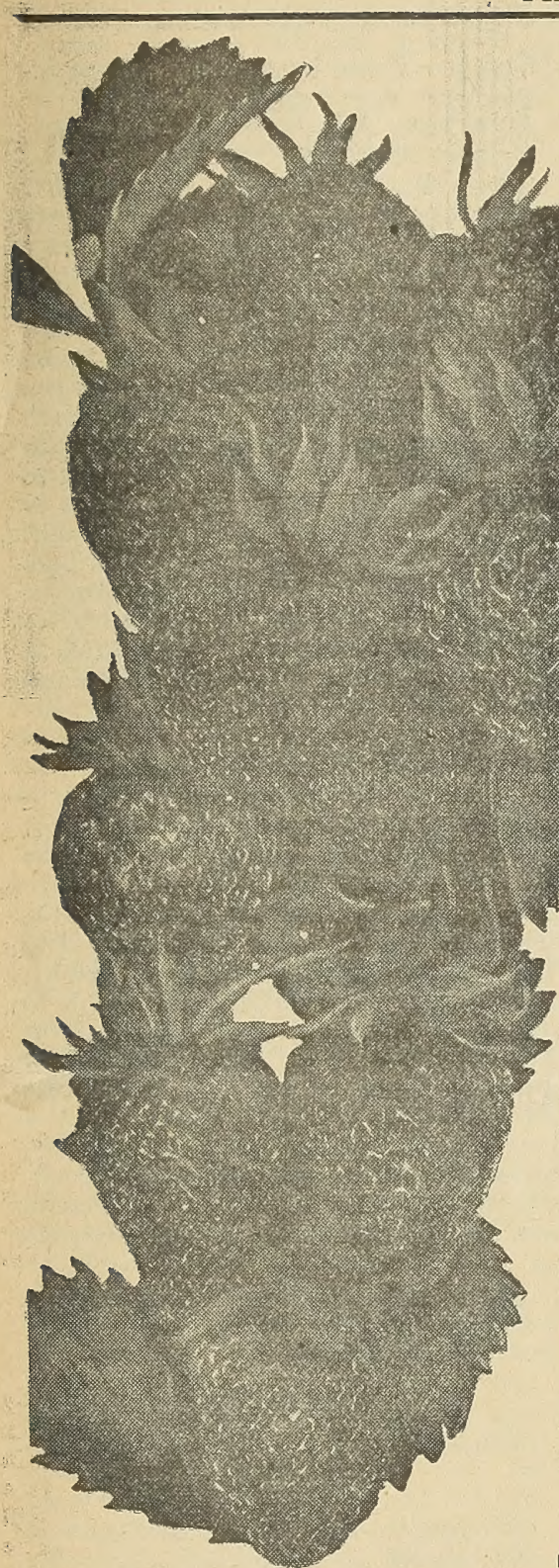

Everbearing Strawberries

\section{Have Made Good}

There can be no possible doubt any longer about the Everbearing straw. berries. They have made good and then some. If you have been putting of planting them, wa'ting for them, to show whether they are a good thing or a fake, you don't need to wait any longer. They have proved the past four seasons that they will bear all summer, every summer, from earlier than the others till the ground freezes in the fall. Ripe berries, green berries and blossoms all the time. And the best berries you ever tasted, big and red and sweet and juicy. Real strawberries.

We use them for regular spring crop too, as they are the earliest we can get, and good size and extra good flavor, and they bear enormously.

\section{Reduced Prices on Straw- berry Plants \\ Progressive Everbearing}

25 plants__.

50 plants

100 plants

200 plants

300 plants

500 plants

Send your order now and we will send you the plants by parcel post at the proper time for planting.

These prices are all postpaid by parcel post, safe delivery guaranteed. Ask for prices on large amounts. Plants are guaranteed to be genuine Everbearing or I will replace them 2 to 1 .

\section{1,000 Everbearers for $\$ 12.00$}

We have a surplus of Progressive Everbearing strawberry plants. Fine plants, too. They wintered uncommon well and are turning out much heavier than we had anticipated. They are the genuine Everbearing kind.

So we are giving you a bargain if you can use 1,000 or over. $\$ 12.00$ per thous and, not postpaid. Safe arrival and quality guaranteed. If you can't use that many yourself, make up a club order and divide with your friends when they come. You ought to plant that many yourself, though. It will set just about one-tenth of an acre and make you more money than any full acre on your place.

You will get more than enough berries the first year to pay all expenses, and have a beautiful patch to make an enormous yield next spring and all next summer.

Go to it. You can't lose. I don't know any better way for you to mako money and make it quick. with ordinary care.

\section{Plant Strawberries}

This is a good year to set out small fruits because you want to plant such crops as will produce quick results.

Strawberries are the ideal quick fruit crop, and especially the Everbearers, for they are the only fruit that will make a crop the first year they are planted. We have the best crop of plants this year that we have ever had and will be so fixed that we can give you both good service and good stock because we are devoting special attention to small fruits and ornamental shrubs.

Our prices on strawberry plants are lower than last year and the plants better than ever. We can supply the old favorite, Progressive Everbearer, and in the common varieties, the Senator Dunlap and the Aroma.

Put your order in early and we will do the rest. We will send them at the proper time to plant or any certain time you name.

\section{Our New Garfield Ever-} bearing Strawberry

We announced this new variety last year and it is a good one. It makes more plants and is a little heavier fruit maker than some of the other everbearers, and the fruit is as good as any, Progressive Everbearers but a good eater.

Our prepaid prices are as follows: 25 plants

50 plants

\section{Champion Everbearer}

This is a new variety of Everbearing strawberry which we grew last year. It seems to be practically the same as the Progressive, possibly a selection from it. A good berry and a good bearer. We can supply plants of our own growing. Prices same as the Garfield, $\$ 3.00$ per 100 postpaid. not so red and sweet, perhaps, as the 


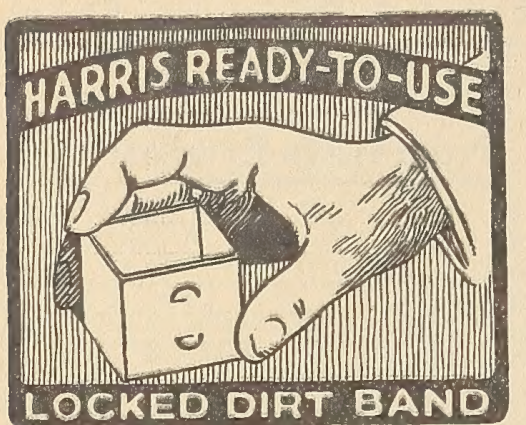

Plant Bands or Paper Pots

These plant bands are all right. They are the finest thing in the world to transplant plants of every kind. They are cheap, easy to use, and very satis. factory.

They come already foldei and set up. All you have to do is open them, set them in a box close together, and fill with dirt, and put in the plant. They can be had either with or without bottoms.

We do not bother with bottoms in them at all, but just use the sides, and we find they handle just as good when they are ready to move as if they were bottons in the bands, and it is easier when they are in the dirt for the roots to get out on account of there being no bottom to the band.

They come in various sizes, but we like the $2 \times 2$ size the best. We can, however, furnish the other sizes if wanted, but the $2 \times 2$ we expect to always have on hand and can furnish promptly. and they are the kind that most people want.

Here are the prices, delivered to you postpaid :
$2 \times 2$ inches_._._.\$1.25 per 250
$3 \times 3$ inches_._-. 1.50 per 250
$4 \times 4$ inches $\ldots-2.00$ per 250
All delivered postpaid.

If you can use them in larger quantities, we cari make special prices by the 1,000 , and lower prices in full case lots, to go by express at your expense either from our place or from the factory in Minnesota.

For instance, size $2 \times 2$, which is the popular size, would cost you $\$ 2.75$ per 1,000 , or $\$ 11.50$ per case of 5,000 , and other sizes in proportion.

Size $3 \times 3$ costs, $\$ 3.95$ per 1,000 and size $4 \times 4, \$ 4.65$ per 1.000

If you want them with bottoms, add 20 per cent to all prices.

\section{Pansy Plants for Sale}

We will have thousands of pansy plants for shipment after April 15th. They are grown from the finest strains of seed and we can assure all lovers of this beautiful flower that they will be surprised and pleased with the sizo and beauty of this strain of pansies. They will be oent by mail, extra well packed, and safe arrival guaranteed. 1 dozen, mixed colors, postpaid_\$ .75 3 dozen, mized colors, postpaid_ 2.00

\section{Transplanted \\ Tomato and Cabbage Plants}

We are having a nice lot of tomato and cabbago plants grown hero at Shenandoah, and we will be able to fix you out in good shape. They will be ready about April 10, naybe earlter.

Tomatoes, (heavy transplanted plants), delivered by pareil post, postpald, 6 for $30 \mathrm{c}, 12$ for $45 \mathrm{c}, 25$ for $85 \mathrm{e}, 100$ for $\$ 3.00$.

Varieties! Early June, Misoissippi Girl, New Stone, Earliana and Red. head. Also Pepper, Eggplant, and Cauliflower, at the same price.

Cabbage plant:, leading oorto, 12 for $30 \mathrm{c}, 25$ for $45 \mathrm{c}, 100$ for $\$ 1.50$ all delivered by pareel post, prepaid.

Ask for special prices on larger lots of cabbage plants.

\section{Order Plants Now}

There is no excuse for any one not having enough small fruit for his table use during the summer, and to can enough for use all winter, to say nothing of the extra money he might make by selling the extra fruit.

Any back yard is large enough to grow some drape and small fruits. You can use the vines or bush as an orna mental fence or hedge and yet get your fruit. And then we all have a garden spot that is dug up and planted every year, and you can put out some straw berries in one corner and not miss the ground, but after you once grow your berries you will miss them.

And the beauty of the small frui business is that they give you results and crops 80 much sooner than the trees-that is quite an item you know.

\section{Celery Plants}

We will be able to fumish celery plants this year, good big plants of good varieties. Will probably have them mailed direct from grower in Michigan. They will be ready soon now, and can be had all through May and June.

\section{Prices Postpaid}

100 plants $\$ 1.00$

200 plant 1.70

300 plants 2.35

400 plants

3.00

500 plants 3.60

1,000 plants

No order accopted for less than 100. Special prices on large lots to go by express, at your expense.

\section{Third Order This Spring}

"Dear Mr. Field: This makes my third order this spring, so you see I must be satisfied, and I like Seed Sense fust fine. It sure helps me a lot by reading some one else's letters, and knowing they are satisfied ao. In all the seed I got from you, I believe every seed came up and is growis So here is another order. I remain," -Mrs. Joe G. Plafcan, Carlisle, Ark.
Plant Everbearing Strawberries for Quick Money

There is only one kind of frutt that will bring you any returns the first year and that's the Everboanting Strawberries, Set the plants in Aprll or early May and they will begin to boar at once. Will bear heavily in July and clear on until frost. They will much moro than pay expenses the first year. Then you will have a boautiful patch for fruit or plants the next spring. With good luck you can count on a quart to each plant set. And a lot of plants to sell besides. Figure it up for yourself.

1,000 plants will get a goed sized bed 10,000 plants will set an acre, We are making a spectal price or surplus offer of $\$ 12.00$ per thousand, not postpaid, in lots of 1,000 and over. Get busy and get patch.

\section{Sweet Potato Plants}

We will be able to supply first elass sweet potato plaxts from May 1 to Jine 15. Will have some bere at Shenandoah, some at Fruitland, (near Muscatine), Iowa, and some at Rogers, Ark The ones at Rogers are all Nancy Halls, as nothing eles is allowed there, but at the other places we can furnith both Yellow Jersey and Nancy Hall, and from Fruitland we can also supply the Early Prolific. This Early Prolific is a new variety, looking like Yellow Jersey but earlier and larder, and deeper color Can be had only at Fruitland. We can not furnish plants of the red varieties we do not grow nor advise them.

Prices postpald direot from grower, whichever place seeme best. Safe arrival guaranteed.

VARIETIES
Nancy Hall Yellow Joruey
Early Prollfic
(No others)

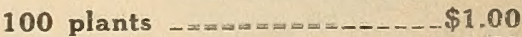
200 plants

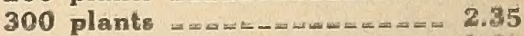

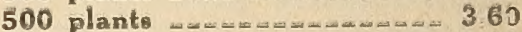

1,000 plants $-\ldots \ldots-00$

No orders accepted for less than 100 plants of a kind. On larger quantities to come by express at your expense whichever place seems best, $\$ 5.00$ per 1,000 .

\section{Likes our Seeds}

We have been getting your catalog for 10 years now and have probably missed sending you an order 4 or 5 times in thase years, but I must say with truth that you are entitled to the business just from the standpoint of "seeds that grow," We were just suying the other day that with the experience we have had that we ahould cont fine ourselves to your seeds, (Last year whe ourselves fo yours, and are gaing to do so We got three of your cataloges do so. We got three of your cataloges retently and guve 2 of them to neightars laid considerable stress on the quality of yours. We shall send it an order in a week or two. Yours for eantinued succelsb. or two. Yours for eothtinired su 


\section{Less Corn-More Clover}

Everybody is talking "less corn and more clover," and I guess that is the only thing that will bring back the price of corn. A 25 per cent reduction corn acreage and a corresponding increase in clover and sweet clover and hubam and alfalfa will help cut all around. I'm for it.

But what corn we do grow, we must make count, every acre of it. Better preparation, better cultivation, better seed.

If you haven't got first class seed of your own we can fix you out with the right kind from here. We can give you the best there is, either white or yellow, early or late. Try us and see.

\section{Varieties of Seed Corn}

I haven't foom here to give long de. scriptions of all of the kitids of seed corn we have, but have given a con densed list of them in the price list and will be glad to give you full information on any of them on request.

\section{Grading}

The grains, in all varieties, except ensilago and fodder corns, are graded to 1-5 inch in thickness, and either 20-64, 22-64 or 24-64 in width, according to variety. Absolutely no butt or tip or uneven grains in our corn.

\section{Samples Free}

I will be glad to send you smal samples of any of the different kinds of seed corn on request. Ask for the varieties you are interested in.

\section{Safe Arrival Guaranteed}

We guarantee safe arrival of seed corn to you, and in case any shipment arrives short or damaged, we will, upon receiving proper proofs from you for filing freight claim, make good the loss to you, oither by refiling or refunding and collect the loss from the railroad

\section{Northern Grown Seed}

We always have a supply of these extra early varieties grown in South Dakota or Northern Iowa, so as to be sure of extreme earliness for our north ern trade, and can generally supply any of the extra early varieties named above for shipment direct from the grower in South Dakota or from here along with other seed, as you prefer.

\section{Change in Prices}

These prices on ebrn will probably stand all spring, but some varieties may go sold tut. Out of Mule Corn now.

Our seed corn does well over a wide range of country. If you need seed corn I am sure we can suit you.

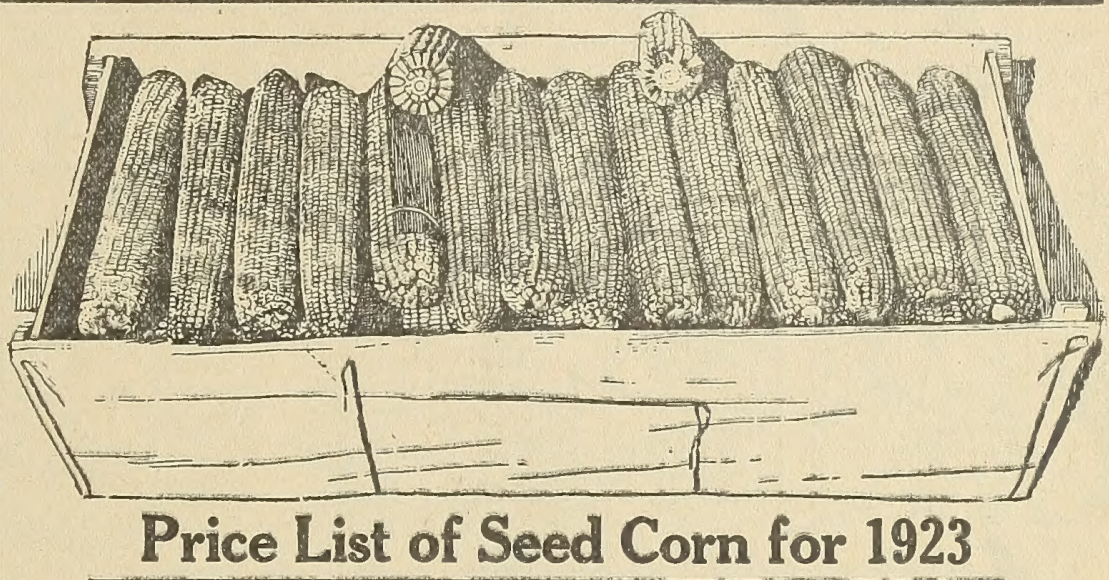

These prices are for strictly first class seed, extra selected, butted and tipped by hand, shelled and triple graded, tested before shipping, and tests marked on each sack. Prices are $\mathrm{f}$. 0 , b. here, sacked in strong, new sacks, with no extra charge for sacks.

\section{Same Price on All Varieties}

We will make the following low prices on all the standard varieties.

10 bu. 5 bu. 2 bu 1 bu. $1 / 2$ bu. Pk. Gal, $\$ 2.75$ per bu $\$ 2.85$ per bu. $\$ 2.90$ per bu. $\$ 3.00 \quad \$ 1.75 \quad 1.00 \quad 60 c$

\section{Standard Main Crop Varieties}

Shenandoah Yellow. Large, rough, ye llow, cattlo corn. Heavy yielder. Shenandoah Special. Similar, but smoother, and about 10 days earlior. White Elephant. Long, smooth, white, heavy ylelder, stands hardship well. Reid's Yellow Dent. Large, yellow, fairly rough, extra fine typo of ear. Boone Co. White. Deep grained, rough, extra large ear, for good land. Complanter. An improved strain of Boone. Longer ear. Beautiful grain. Iowa Silvermine. Medium size white corn, good for old or thin land. St. Charles. Red cob, white corn, strong grower; popular in Missouri. Improved Calico. Striped red and yellow. Good yielder and fairly early, Iowa No. 10. A second-early yellow corn from the state college. Good.

All of the above are home grown here in Southwest lowa, and are the but varieties grown here. All sell at prices named above.

\section{Early Corn-80 to 90 Days}

These are the varieties for planting in the extreme north, or for replanting or for extra early feeding corn here and south. Most of them can be supplied in either home grown or Dakota grown. The Dakota seed is generally carlier and smaller. Please specify if you have any choice. All same price.

Silver King. The standard early white corn for northern Iowa.

Northwest Yellow Dent. A similar early corn, only yellow. Very early.

Red 90 Day. Very early and hardy. Red grain with yellow cap.

Flint or Yankee Corn. Earliest of all. Small, smooth and hard.

Mule Corn. A remarkable hybrid. Sold out.

\section{Small Amounts of Seed Corn by Mail}

Shelled seed, large packet $10 \mathrm{c}$, pound $25 \mathrm{c}, 3$ pounds one variety $65 \mathrm{c}, 5$ pounds $\$ 1.00$. Specimen ears $40 \mathrm{c}$ each. These prices apply to all varieties, postpaid, anywhere in the United States.

\section{Subject to Your Test}

We sell it subject to your own test and approval, and if it is not absolutely satisfactory to you in every way, you can return it at our expense, and we will refund your money and pay the freight. You can't lose on a deal of that kind. You can have two weeks or a month to test it if you wish. All I want is for you to be oatisfied.

\section{Guarantee on Seed Corn}

Of course I can't guarantee you a crop for I can't be there to plant it and tend it, but you can take the seed home and examine it and test it and call in the neighbors; and if you feel that you have been beat, you can have your money back. That's fair. All I ask is, that you give me a fair shake and I will leave matters in your hands. 


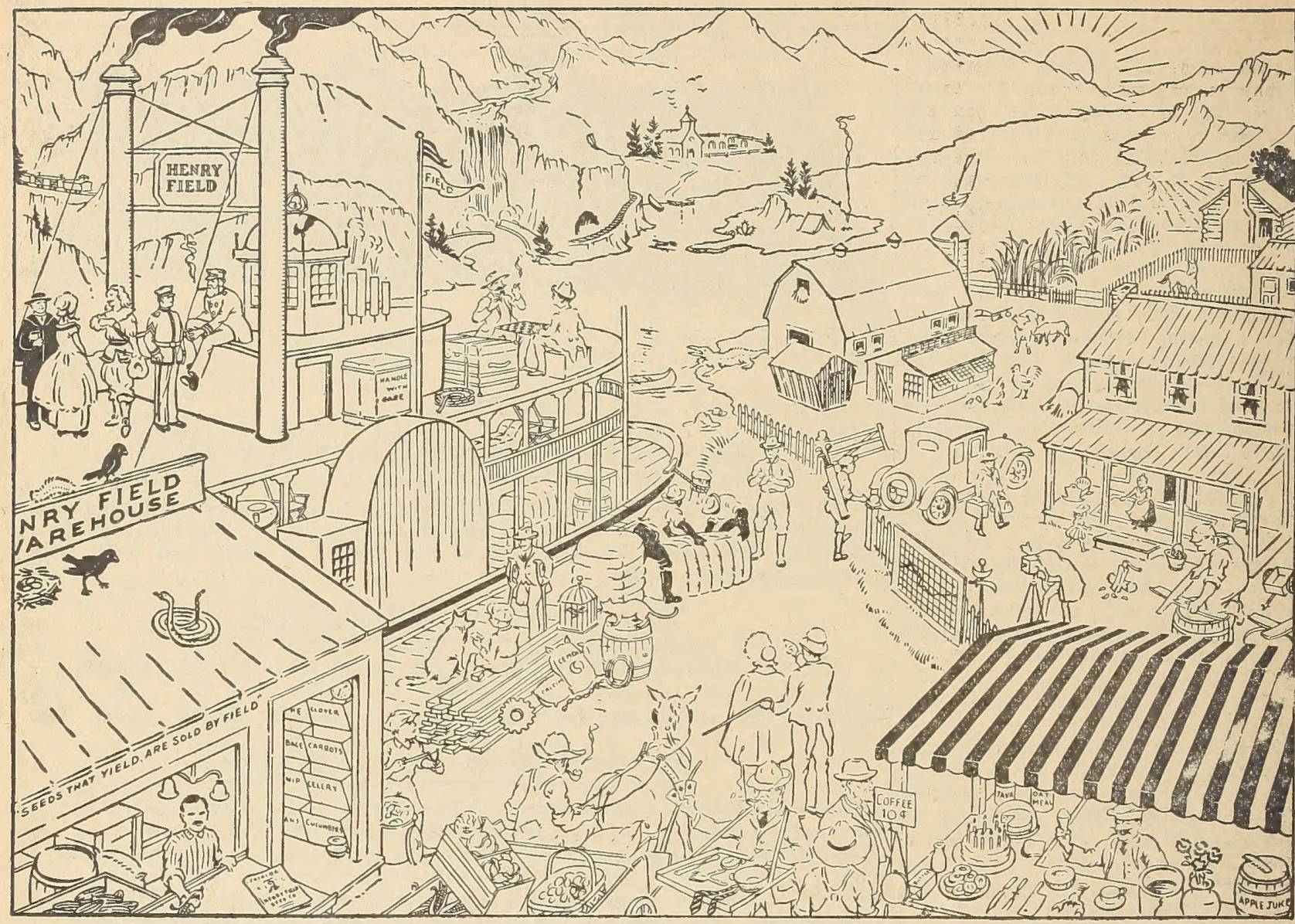

\section{An Easy Picture Puzzle}

I have put in a picture puzzle this time that is dead easy. You can all get in on it. If you like puzzles, and everyone seems to like them, here is one you can have a lot of fun with.

Our Customers Planned It. We wanted to find out what kind of picture puzzles people liked best, so we wrote to several hundred of our customers and asked them, and this puzzle is the result of their answers. We made it the way they liked it.

No Dictionary Needed. One trouble with other puzzles has been that you couldn't get anywhere unless you had the very latest dictionary, but in this you need none, as we have made up a list already, and all you have to do is choose from that.

100 Prizes. Some people complained that the money was usually put all into two or three big prizes so that the "also rans" had no chance, so we made 100 prizes. If you are any good at all you can get in on a prize of some kind.

Only a Few Rules. Sometimes there are so many rules it is confusing, so this time we have made just 5 simple rules. Here they are below. Read them.

\section{JUST FIVE SIMPLE RULES}

1. The prizes will be paid for the nearest correct lists of names of visible objects in the picture made up from our "Key List" printed herewith; each word can be used only once; each object can be named only once; parts of objects can be named.

2. Shenandoah people are barred.

3. All lists and qualifying money must be mailed between March 1, and May 15, 1923.

4. The decision of the judges is to be considered as final. They will make up the correct list from among all the words submitted. Where several words can be used equally well for an object, any one will be counted as correct. Names of winners and the winning list will be printed in Seed Sense.

5 Each correct word will count one point and each wrong word will subtract one point from the score. In the event of a tie for any prize offered the full amount of each prize tied for will be awarded to each tying contestant.
OPEN TO ALL. This contest is open to all, whether you send any money or not.

BIGGER IF YOU ORDER. Of course if you send an order with your answer your prize will be much bigger if you win.

YOU BUY SEEDS and plants and bulbs and such things anyway, and you just as well buy them from us, and qualify for the big money. You'd feel mighty cheap if you had a good list and won $\$ 10$ on it instead of $\$ 500$. ORDER ANYTHING YOU. PLEASE. You can buy anything we sell. Don't care what it is. Anything from garden seeds to Spotted Pigs or anywhere between.

SPECIAL DUE BILL OFFER. If you are not ready to order yet, you can send the money so as to qualify your word list and we will give you a due bill, good

SEND MONEY EARLY. It is important that you send the money in early for it adds $\$ 5.00$ per day to your prize if you win first. If you are not ready to order yet, send the money early anyway. You can order later. HENRY FIELD SEED CO., Shenandoah, Iowa

\section{Over $\$ 2000.00$ In Prizes}

\begin{tabular}{|r|r|r|r|r}
\hline $\begin{array}{c}\text { If you } \\
\text { win } \\
\text { you } \\
\text { get }\end{array}$ & $\begin{array}{c}\text { If you } \\
\text { send no } \\
\text { money }\end{array}$ & $\begin{array}{c}\text { If you } \\
\text { send } \\
\$ 1.00 \text { to } \\
\$ 1.99\end{array}$ & $\begin{array}{r}\text { If you } \\
\$ 2.00 \text { to } \\
\$ 4.99\end{array}$ & $\begin{array}{c}\text { If you } \\
\text { send } \\
\$ 5.00 \text { or } \\
\text { more }\end{array}$ \\
\hline 1st Prize & $\$ 10$ & $\$ 100$ & $\$ 200$ & $\$ 500$ \\
2nd Prize & 1 & 20 & 50 & 100 \\
3rd Prize & 1 & 20 & 50 & 100 \\
4th Prize & 1 & 20 & 50 & 100 \\
5th Prize & 1 & 20 & 50 & 100 \\
6th Prize & 1 & 20 & 50 & 100 \\
7th Prize & 1 & 20 & 50 & 100 \\
8th Prize & 1 & 20 & 50 & 100 \\
9th Prize & 1 & 20 & 50 & 100 \\
10th Prize & 1 & 20 & 50 & 100 \\
\hline \hline
\end{tabular}

11 th to 50 th prizes. Up to $\$ 10.00$. of the double the amount qualifying money sent.

51 st to 100 th prizes. Up to $\$ 5.00$ qualifying money sent.

$\$ 5.00$ per day extra. If you send your win the $\$ 500.00$ order in early and per day extra for each day ahead of May 15 , that your qualifying money is received If you win one of the $\$ 100.00$ prizes, we wil pay $\$ 1.00$ per day. Good wages, what?

\section{Sure to Win}

If you order seeds from us you are a winne anyway, for you will have a great garden and get your moneys worth, and lots more out of it. whether you work the puzzle or not, and if you work the puzzle you should send an order so money. Send for our big catalog, you'll like it. HENRY FIELD

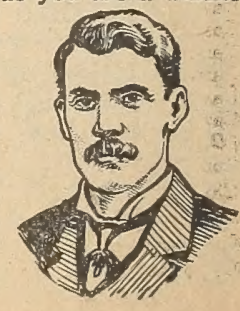




\section{Here is the Key List for Our Puzzle Picture}

It is supposed to contain the name of every object in the picture (and a lot more besides that are NOT in the picture), These extra words are put in to test your judgment. Some objects that appear in the picture are not named in the Key List, but you are limited to this list, anyway. If the name is not in the Key List-don't use it. You see the fool artist put in some things not ordered in our list. You'll have to watch out for them.

(Words in italics are not to be used. They are definitions of the word just before, for your information and help.)!

Mark on this list names of the objects you can find in the picture and then copy the words neatly for your answer.

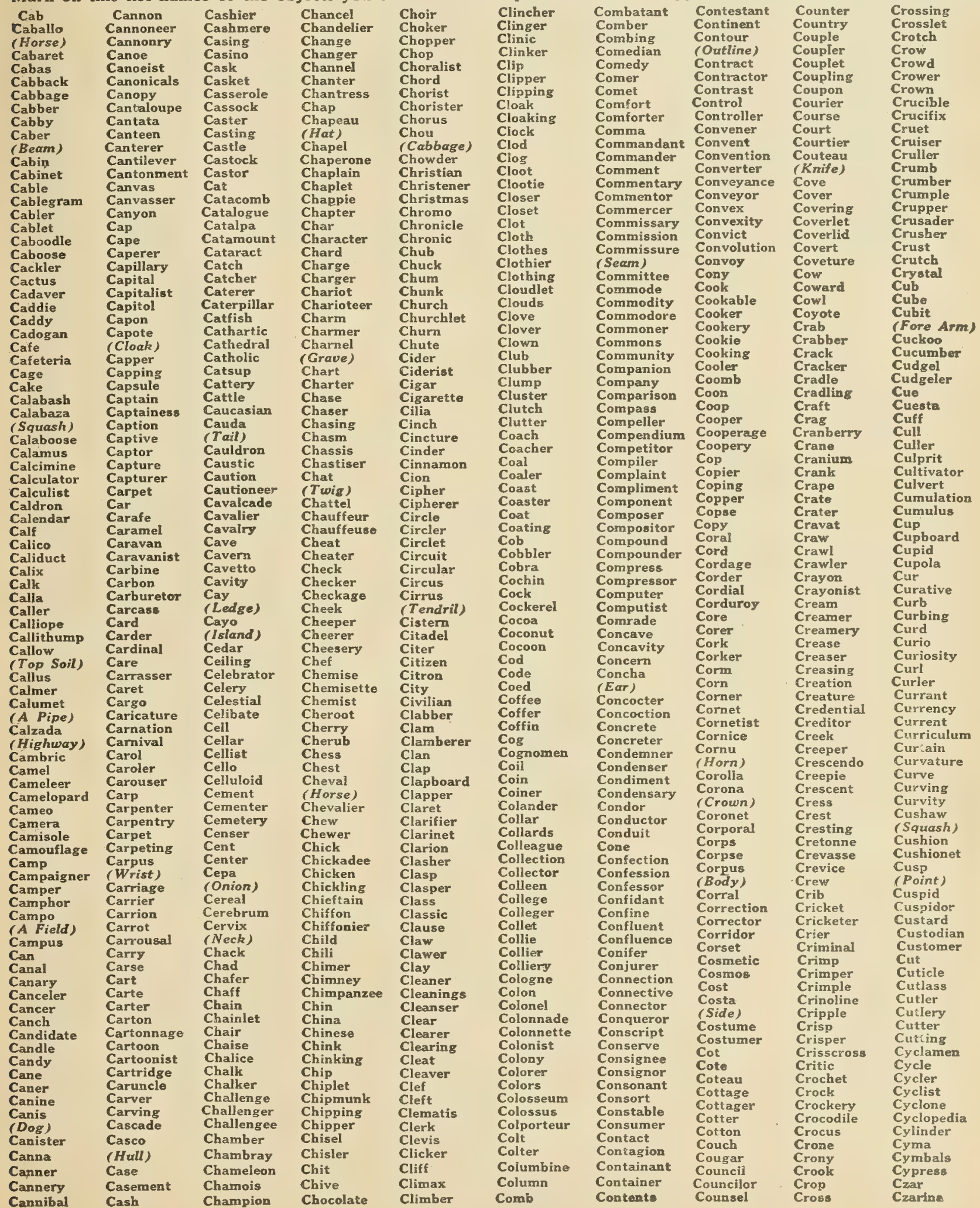




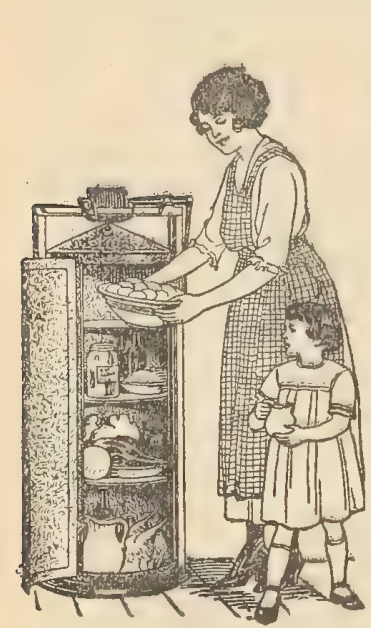

\section{Sanitary Iceless Cooler}

Keeps Your Provisions Cool During Hottest Weather Without Ice

This Sanitary Iceless Cooler serves every purpose of an ice Box with no expense for ice. It is a practical necessity on every farm.

It thay be installed in any open or dug well, or if you have a drilled or driven well which cannot accommodate it, you can make an excavation in your cellar or other convenient place 8 to 10 feet deep and lined with 18-inch tile. At this depth the temperature is as low as 55 degrees. You call fllake this excavation directly under the kitchen if you wish and the outfit can then be installed right in your kitchen, where it will be handy at all times. It is simply a "dumb waiter," and everything you want may be obtained in a moment. Saves expense for ice. First cost is only cost. Any handy man can easily install it. Provision chamber is bug and aninal proof. It protects your foodstuffs from insects and prowling animals as well as keeping them cool and preventing their spoiling even in hottest weather. Provision chamber is 40 inches high and 14 inches in diameter with three adjustable shelves. Shipped from factory In Iowa.

PRICE-Outfit complete with windlass, galvanized steel cable, and guide rods extending $8 \mathrm{ft}$. into well as shown, $\$ 18.75$. Shipping wt. $95 \mathrm{lbs}$.

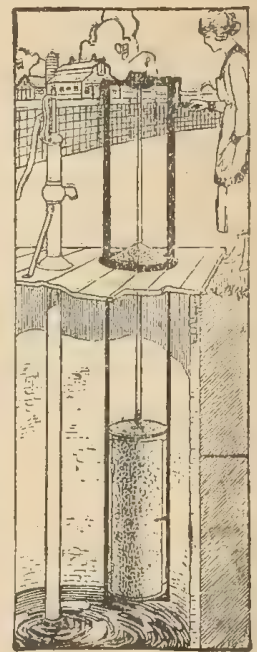

\section{Choice Hand-Picked Cane} Heads

Don't forget that we have carefully selected and hung before frost, heads of cane from most of the varieties I have mentioned. They are the nicest cane heads we havo ever had and I really believe 2 pounds of this selected seed will plant an acre, using a corn planter with a cane plate.

Besides the regular ever-day varieties, can also supply limited amount syrup cane heads of Silver Tip, Arizona origin; Superior Orange, Central, Ill,; The Ashbaugh, Northern Iowa; Jap. Rib bon, Arizona; Red Amber, Central Kansas, and a new one to us from Colorado.

Price-We offer this, while the supply lasts, at $40 \mathrm{c}$ per $1 \mathrm{~b}$., or $3 \mathrm{lbs}$. for $\$ 1.00$, postpaid. Here is an opportunity to buy cane in the head and see what you are getting, absolutely cane seed, too, for making honest-togoodness sorghum syrup.

Postpaid Prices on Field

\section{Seeds}

We find there are lots of people who want only small amounts of field seeds, such as Cane, Rape, Cow Peas, Soy Beans, etc., and for their convenience we have arranged to sell practically all the common field seeds at the following prices, postpaid, in zones $1,2,3$, and 4, with $2 \mathrm{c}$ per $1 \mathrm{~b}$., extra, for, each zone beyond 4.1 tb, $25 \mathrm{c}$; 2 tb $8,45 \mathrm{c}, 3$ tos, 65c; 5 tbs, \$1.00.

Syrup Cane, all kinds

Soy Beans, all kinds.

Cow Peas, all kinds.

Field Corn, all kinds.

Willet, all kinds Fodder Cane

Felerita

White Kaffir

Milo Maize

Canada Peas

Buckwheat

Colorado Peas

Velvet Beans

Blackeye Beans

Dwarf Essex Rape

All the ame price.
Hen Jewelry

\section{Aluminum Adjustable Legbands}

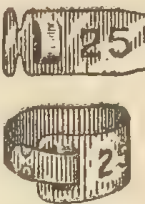

Lit

PRECES :-12 for $20 \mathrm{c}$ 25 for $30 c, 50$ for $45 c$, 100 for $75 \mathrm{c}$, all postpaid

These are the latest style, pure alum. inum, adjustable to any size poultry, numbered 1 to 12,1 to 25 , and 1 to 100 . We carry a good supply in stock all the time and send them postpald at prices named above.

\section{Pettey's Poultry Punch}

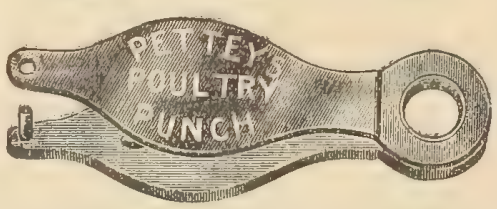

For marking little chickens in the web of the foot. Price $35 \mathrm{c}$ each postpaid.

\section{Plant Plenty of Sudan}

The past season has demonstrated more than ever the value of Sudan for hay, pasture and forage. We sold more seed than ever last spring, and expect to double our sales this spring. Everybody has success with it and wants more. It does well everywhere.

\section{Liked His Pig}

"The hog you sold the came Saturday at ten o'elock and was in fine condivion. Must say $I$ am certainly well pleased with him. He is just the type of a hog I was loaking for, but must say, Mr. Fileld, I was surely surpried when he camp. I was in Springfield that day, but my father-in-law unloaded him. Every man that knows a hog thinks re is a dandy." "warthur Loinson, New Berlin, Ill.

\section{Common Strawberries}

Senator Dunlaps and Aromas

We have arranged with a first class grower to furtish us with plants which we consider by far the best of the ordinary strawberries, and we can fur. nish you what you want of them at tho following prices:

Strawberries, 50 for $65 \mathrm{c}$; 100 for $\$ 1.35 ; 20$ for $\$ 2.25 ; 500$ for $\$ 4.00$, all postpaid in zones $1,2,3$, and 4 . Add 10 per cent per zone beyond zone 4.

We can also furnish fine plants of Aroma, the great southern strawberry, at the same pricos as the Senators.

\section{Peony Blooms for Decora-} tion Day

There is one day in the year that the peony is the national flower, and that is Decoration Day; There is no flower which so abundantly fills the bill for decorating the graves of our loved ones as the peony. On our grounds we have peony plants growing and alwayg have thousands and thousands of the blooms for Decoration Day, unless the season is extra late. We can ship to you anywhere within about 400 miles. Send your order a week or two in advance and state just when you want them shipped. Price, delivered prepaid in zones 2,3 , and 4 , either by parcel post or prepaid express, $\$ 2.50$ per dozen. Ask for special prices on large lote to go by express at your expense.

\section{Genuine Maple Syrup}

A customer in Vermont is shipping tis some genuine Maple Syrup, and we can spare a little of it. Send check for what you want. If out, will return cligck. Price, \$3.00 per gallon can, net f。 b. hore. 


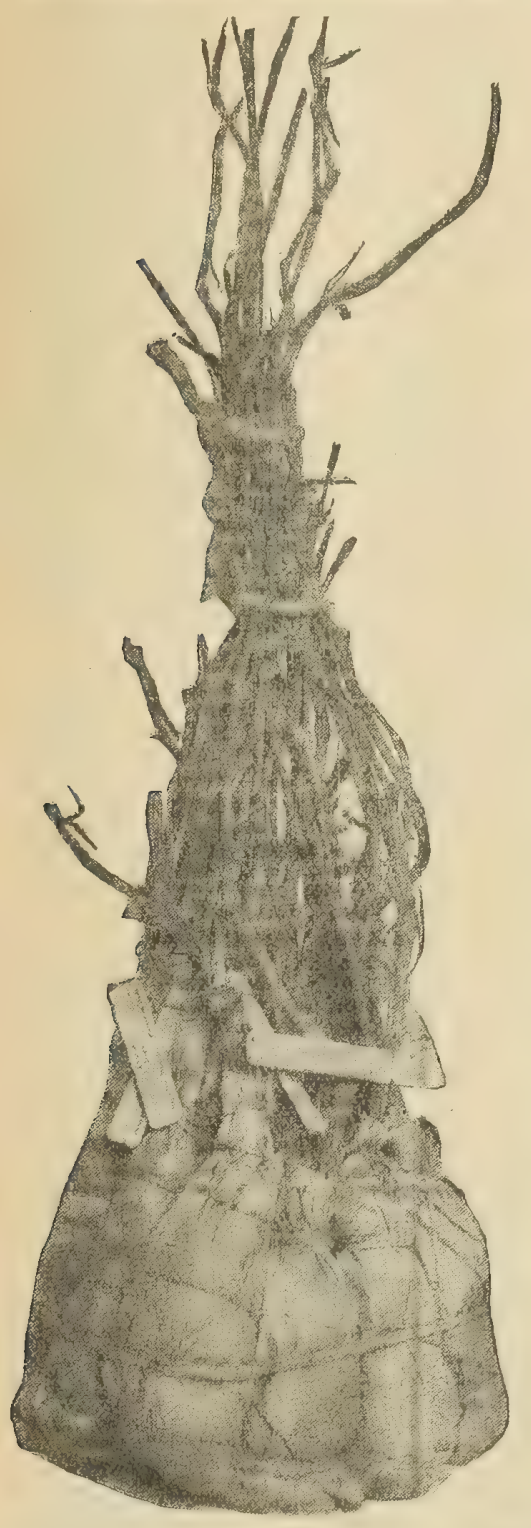

\section{Sample of Our Grapes}

Some one asked if our grape vines were teal vines or little things. Here is an exact photo of how they look and how we pack them. Some class.

We wrap each plant separateily with moss on the roots and label each plant so there can be no mistakes. Then the whole bunch is tied like this, and a heavy wrapper put around the whole thing and they are sent to you postpaid or by prepaid express.

They will reach you in perfect condi. tion, and big fine plants like the ones shown. We will guarantee that they will please you.

We raised these vines ourselves right from the cuttings and they have alwayg had the best of care, and I don't believe you can get better ones anywhere.

Our prices are right. They are lower than you will get most places and $I$ believe we give you better plants than most. Iry it and see.

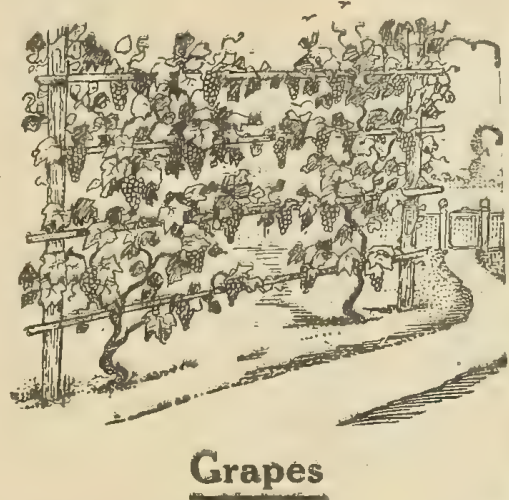

More grapes will be planted this yoat for both commercial atd domestic pure poses than ever before, We grow hare, on our trial grounds, some of the best rooted and hardiest plants I ever saw. Grapes are a profitable crop to grow.

Everybody should have a few grape vines in the home garden. There is scarcely a yard so small, either in the country " city, that room for from one to a dozen or more grape vines cannot be found. They can be planted alongside the louse or trained over fences, trèllises, of đoorways, and made ornainental as well as usefui. They do well on any soil, except low, wet ground. To succeed best they should have a free exposure to sun and ait. Have your ground mellow and plant about two inches deoper than they stood in the nursery, If planting along side fences, plant six feet apart. If in open ground, in rows 5 feet apart, and 6 foet in a row, Cut back well when planted out, Lave not more than three buds on vine the first year and then prune severely every yeat, cutting out the old. est wood and leaving strong new vings. We believe in the list we are offeritin is included the best arieties drown in this country.

See our big catalog for descriptions of the different varieties. Not room to tell it all hero. You just about as well otop with Concord, Moore's Early and Word

\section{Prepaid Price List of Crapes}

At these prices all grape vines will be delivered by parcel post or prepaid express, all charges paid, in zones 1, 2 , 3 and 4. If you live outside of zore 4 , add 10 per cent per zone for prepaid. (Six or more at dozen rates).

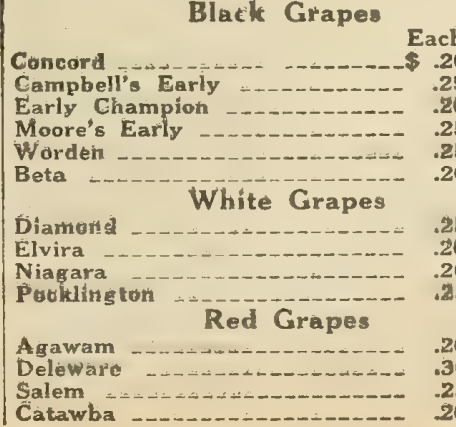

Doz. $\$ 2.00$ 2.50 2.00 2.50

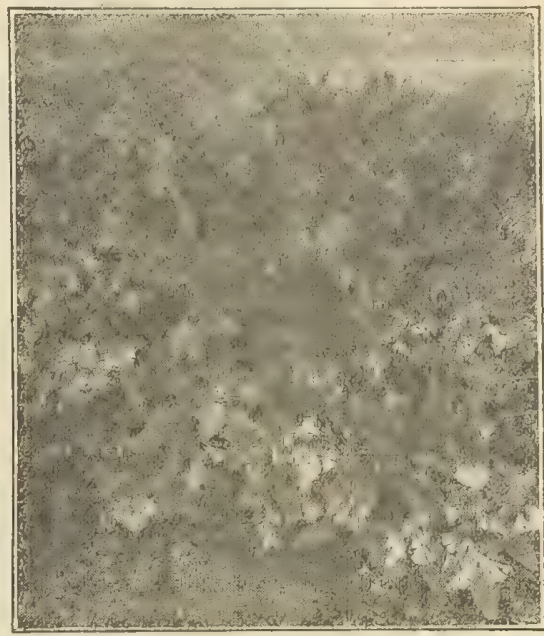

A Fern Bed for $\$ 3.00$

These are not house plants but the big hardy "Ostrich plume" ferns that grow on the north side of the house. They are beauties. The picture show them at my house with wild flowers in front of them. I can supply large plants of these at $\$ 3.00$ for 10 , or $\$ 5.00$ for 20 , postpaid. Single plants 50c postpuid. They are hardy anywhere.

\section{Berry Boxes and Crates}

We have plenty of berry boxes and crates, and can make shipment on them either from Shenandoah or from fac. tory in Omaha. The boxes we use are really baskets. They are the full quart nice little baskets, which are used so much by the best southern strawberry growers. The crate is what is called the American Ventilated Crate, which holds 24 of these baskets.

Here are the prices, net $f, o, b$. here, you to pay express or freight

Crates, complete with 24 baskets 550 Crates alone $30 \mathrm{c}$ each Baskets alone $=-\approx=-m=\$ 1.10$ per 100 Backets only $-\infty-\omega-\$ 10.00$ per 1,000 Market Baskots, 16 bu. - $90 \mathrm{e}$ per doz。 Market Basketo, $1-3$ bu. $80 \mathrm{c}$ per dox. Market Baskets, peck_-_80c per doz. Grape Baskets, 4 qt. $\$ 6.00$ per 100

\section{Likes Our Two Year Roses}

"Dear Sir: My order filled complete. got my Rase buahes yesterday, Oh, joy, what fine bushes. I have spent many a dollar on rose bushas, for I am fond of them but never had such fine ones as these. im more than pletised with them, for if ihese don't grow, nothing will. I sent for 8 rost bushes from up north last year, and I could hold all 8 in one hand, and orly one grew. That is, I hept it greern, and it is as big as a lead pencil now. These $t$ got from you at feal ones. Thank you a thousand times for the premium Hibiscus,"

Mrs. Herbert E. Hall, Norwood Park, III.

\section{Good Grass Seed}

I eure got a gaod front yard out of yot

mixture grass seed, planted last March." 
BEAUTIFUL OSTRICH PLUME Chrysanthemums

M. FROMONT-This variety

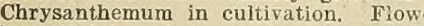

beautiful in color and character of flo

form. Consider the best white of the plumed type. 25e each; 3 for $72 \mathrm{c}$.

LOUIS BOEHMER-Most beautiful shade of lavender pink, shaded with silver-pink on end

PEARL OF LYONNAISE-Bright, clear golden-yellow, somewhat plumed; quite full:

SPECIAL- 25 for $72 \mathrm{c}$.

SPECIAL-One each of above four Ostrich Plume Chrysanthemums, Big Bargains in Plamts bloomers; all different, 98 c.

F. 42 Everblooming Roses, 2 Polyantha or Fairy Roses and 2 Climb. ing Roses, 98c

F- 56 Prize-Winning Chrysanthemums-all different, $98 \mathrm{c}$.

$\begin{array}{lll}\text { F- } 6 & 5 & \text { Beautiful Double Geraniums, choice colors, 98c. } \\ \text { F. } 9 & 1 & \text { Double Geranium, } 1 \text { Single Geranium, } 1 \text { Fragrant Geranium, }\end{array}$ 1 Ivy Geranium, and 1 Silver-Leaved Geranium, 98c.

$\begin{array}{lrl}\text { F-11 } & 5 & \text { Splendid Carnations. Beautiful colors and all } \\ \text { F-35 } & 20 & \text { Tea and Everblooming Roses, all different, } \$ 2.24 \text {. }\end{array}$

F-36 20 Geraniums, double and single, all kinds, $\$ 2.24$.

F.41 20 Lantanas, in good variety, will bloom all summer. Unexcelled

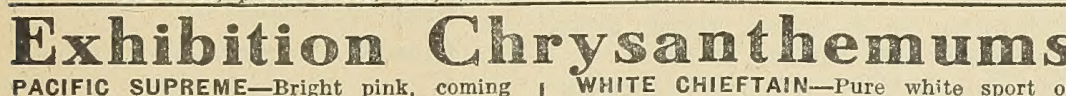
into bloom about the last of August. $24 \mathrm{C}$; 3 for $68 \mathrm{c}$.

CHRYSOLORA-A new yellow variety. Large beautiful blooms. 20c; 3 for $57 \mathrm{c}$.

BLACK HAWK-Late flowering. Dark velvety crimson-scarlet. Blooms of immense size and fine form. 26c: 3 for $74 \mathrm{c}$

MAJOR BONNAFFON-Introduced m a n years, but still a very popular commercial yellow. 24c: 3 for 68c.

Special Offer ${ }_{9}^{\text {One each of above }}$ Show type Chrysanthemums, postpaid, $\$ 1.35$.

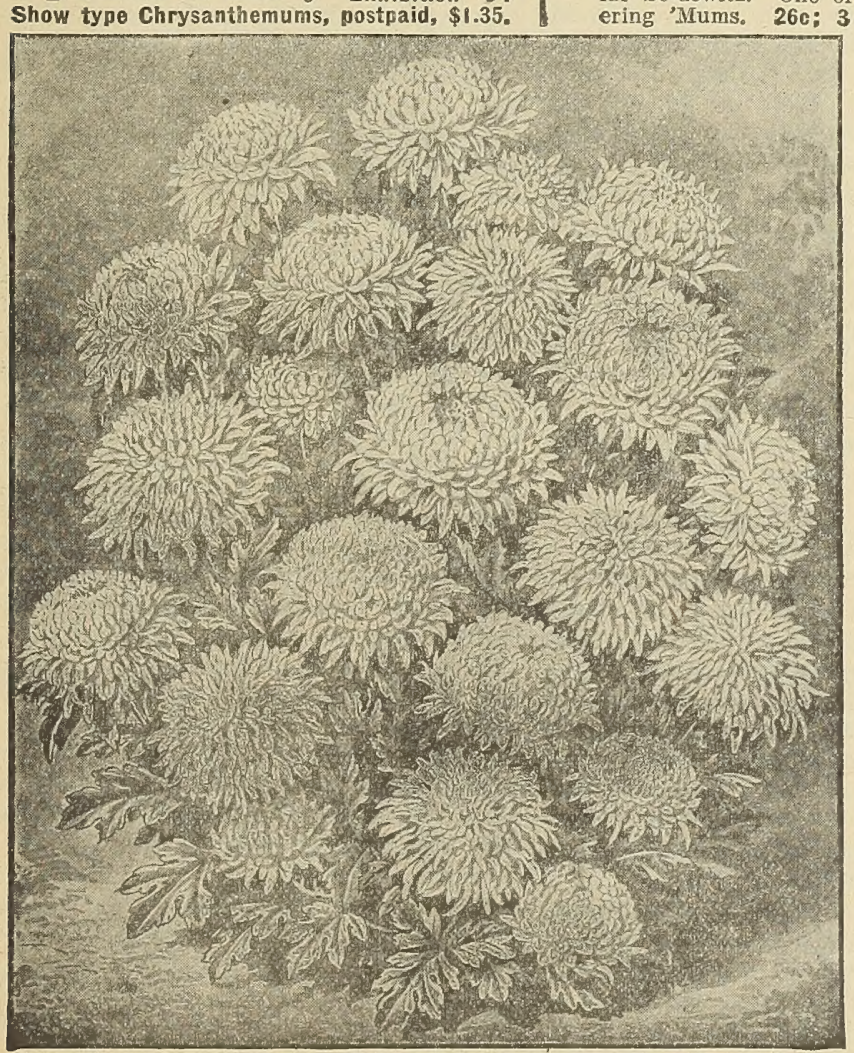

Large hardy free-flowering out-door Clirysanthemum, Homestead, R8c. valuable commercial varieties. $24 \mathrm{c}: 3$ for $68 \mathrm{c}$

WHITE TURNER-Be

APPLETON-At one time the most

largely grown yellow in cultivation. $22 \mathrm{c}$

RED SEIDEWITZ-Re

the popu

or $74 \mathrm{c}$. purest white. 25c; 3 for $72 \mathrm{c}$

and finish. 19c; 3 for $54 \mathrm{c}$.

Hardy Old -

Fashioned without 240.

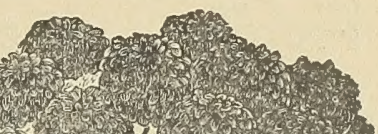

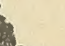
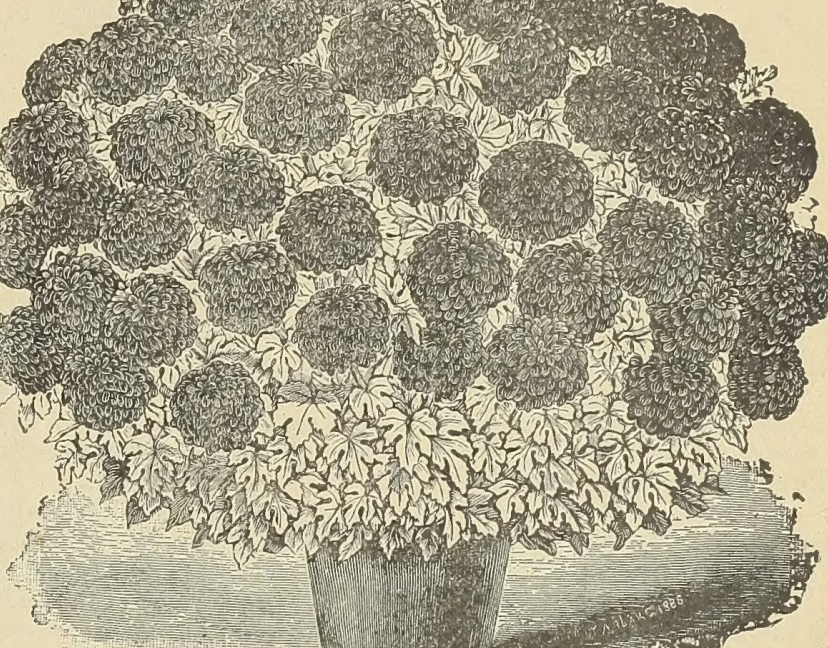

Chrysanthemum Man-0'-War.

8 Fancy Chrysanthemums

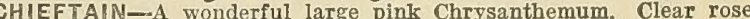
pink. Midseason bloomer. $24 \mathrm{c}$ each: 3 for $68 \mathrm{c}$.
oCONTO-A grand white. Extra large in size with broad incurved petals of snow-ball type; growth robust, smooth, heary foliage. MAN-OF-WAR-Immense, rich dark red flowers. No better Chrys $85 \mathrm{c} ; 12$ for $\$ 2.88$

TINTS OF GOLD-The earliest of the bronze variety to bloom. Fine variety. $22 \mathrm{c}$ each: 3 for $63 \mathrm{c}$; 12 for $\$ 2.10$.

GLENDALE-Exceedingly brilliant crimson, richly shaded with Scarlet, Very distinct, 22c each: 3 for $63 \mathrm{c}$.
YYNW00D

LYNWOOD HALL-Japanese incurved of perfect form, pure white. Stiff stem and beautiful foliage, $28 \mathrm{c}$ each; 3 for $80 \mathrm{c}$ : 12 for $\$ 2.69$. foliage. $22 \mathrm{c}$ each; 3 for $63 \mathrm{c} ; 12$ for $\$ 2.10$.

W, considered by many the Queen SPECIAL OFFER-The 8 fancy Chrysanthemums described above, including Man-0'-War, \$1.35.

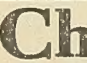

\section{Chrysar}

santhemums fall flower. It is now universally planted; growing anywhere and producing wonderful results with little attention. It is a plant

HOMESTEAD-Strong shade of pink. Has no equal for size. 28c EXCELSIOR-Deep yellow flowers borne in clusters. 20ce

VICTORY - Leading large flowering white pompon. 280.

AUTUMN GLOW-Coppery bronze with red tinge. 25c.

PRINCE OF WALES-Pure white; button type; solid mass of bloom. $20 \mathrm{c}$.

INDIAN-Soft red flowers of good size. None better. 260

CHALDON-Reddish crimson with gold tips. 24e.

NORMANDIE-Delicate pink of recent introduction. 200 .

SPECIAL OFFER-Any three of the Hardy Chrysanthemums listed above, 62c; any five, $90 \mathrm{c}$; all ten above, $\$ 1.62$

HARDY CHRYSANTHEMUMS are unexcelled for planting along foundation walls, around porches, ezc. Special, 20 Hardy Chrys anthemums, in assorted colors, our selection of variotios, $\$ 1.69$. 


\section{Field's Spotted Hog Sale}

\section{Fairly Good Crowd and Prices in Spite of Bad Roads Average Over $\$ 73.00$}

\section{(From Shenandoah Daily World, March 21, 1923)}

The Henry Field Seed Co., certainly lost out this time on their claim of being able to pick sale dates with good roads and good weather, but they pulled off a pretty fair sale in spite of everything, making an average of $\$ 73.01$ on about 100 bred sows, and $\$ 47.70$ on 15 fall boar pigs.

The blizzard of Sunday put the roads absolutely out of commission and crippled train service badly, and it looked Monday like there could hardly be a sale at all, but with clearing skies and a little better train service Monday, they decided to go ahead with the sale anyway, and they were agreeably surprised with a fairly good crowd, some good buyers, and fairly good prices.

The storm probably took $\$ 30.00$ per head of $f$ the average, as with good roads and weather it is practically certain an average of over $\$ 100$ would have been made, but the buyers who were present got the benefit of some very fine animals at bargain prices.

The usual Field lunch was served at the pavilion, and another old time music concert was put on. The sale was conducted by Chas. Taylor and R. E. Miller, and their assistants, in their usual snappy fashion.

About 100 bred sows and 15 fall boar pigs were sold in less than three hours, at prices ranging from $\$ 55.00$ to $\$ 117.50$ on the sows, and $\$ 35.00$ to $\$ 70.00$ on the boar pigs.

The top of the sale was No. 24 at $\$ 117.50$, to Dr. H. R. Noble, Shiloh, Ohio with a close second on No. 1 at $\$ 112.50$, to Ground \& Son, Juniata, Nebr.

The top boar was No. 132 at $\$ 70.00$, to Houchin \& Hoyt, Winside, Nebraska.

Another bred sow sale is to be held by the Field Seed Co., on April 17, and it is to be hoped that they will strike better weather and better roads, but you may rest assured they will go ahead with the sale anyway, rain or shine, and sell hogs to the people who do come.

\section{About the Spotted Pigs}

We have a nice crop of spring pigs coming on, and will have spring pigs to sell some time in June or July.

We don't like to sell them when they are too small. There is no use writing to us for prices on six weeks old pigs, for we don't sell them that way. Little pigs don't ship well. They ought to be allowed to get at least 8 or 10 weeks old before they are weaned, and after that they have to be vaccinated before we can send them out. They absolutely have to be vaccinated before we can send them out of the state. Inside the state it is better to have them vaccinated than to send them without.

Sometimes inside of the state we ship pigs as young as three months, but outside of the state we generally wait until they are a little older than that so they will have plenty of time to be vaccinated after they are weaned and aro well over their vaccination.

I cannot tell exactly what the price will be yet, but probably around $\$ 35.00$ per head for extra good stuff, either sex.

We have a nice bunch of fall pigs on hand, weighing now from 150 to $200 \mathrm{lbs}$. each, and ready for immediate breeding. These we sell at from $\$ 40.00$ to $\$ 50.00$ each, either sex, and will be glad to fix you out.

If you are looking for an extra good herd boar, we have some specially fine ones we can price you at higher prices. Write and tell me just what you aro looking for, and I will fix you out.

\section{Plenty of Seed Corn}

We still have a good supply of seed corn in all varieties, and it is real seed corn, too. This is one year when you should not make any mistake on your corn. Every acre must do its utmost and that means you must have seed that will grow, and grow strong.

We have the strongest, best seed this year that we have ever had and we know we can suit you. We cannot guarantee you a stand, but we will ship the seed subject to your own test and you can prove for yourself that it is high germination. It shows 94 to 99 for us. That's good enough.

$\$ 2.50$ worth of Farmogerm makes $\$ 150$ worth of Nitrogen.

\section{A Home in California}

My father had a lovely home in Red. lands, California, and since his death the heirs have decided to sell it, as none of us expect to go to California to live. It is a wonderfully lovely house with a great palm tree in front, and roses all over the porch, and orange trees in the back yard, and all the rest of nice things you find in that country. Also with it is a two-apartment cottage, which rents for $\$ 50$ a month.

These two houses will be sold now, and can be bought worth the money If you are interested, I can send you photographs, and give you the name of the California man who has it in charge. H. F.

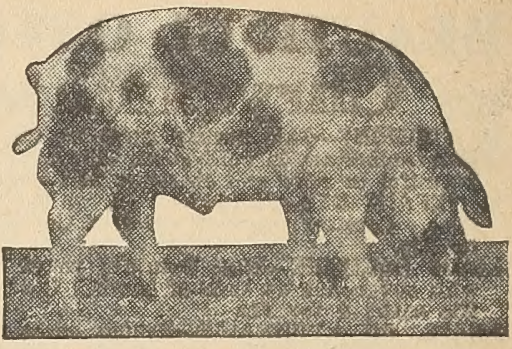

\section{Male Pigs of Any Age}

We always have a fine lot of male pigs on hand of any age, from 3 months to 1 year, and priced at froin $\$ 30$ to $\$ 75$ according to size, age, color, and quality We have all kinds of blood lines and can mate well with anything you already have. Ask for what you want.

\section{Dates of Future Hog Sales}

Tuesday, April 17.

Tuesday, August 21.

Tuesday, October 30 .

\section{Plenty of 90-Day Seed Corn}

I am afraid there is going to be considerable replanting of corn and if you have that bad luck, we are in shape to fix you out with 90 -day corn to replant with. We have a good stock of it on hand, high germination, genuine early stuff, and just what you need for planting any time up to the 20th of June or even later than that farther south. We can furnish either the Red 90Day, Yellow 90-Day, or the White. You may take your choice. Personally, I be lieve I like the red the best of the three and the yellow would be my next choice.

The very earliest thing we have is the Flint corn, which we can furnish either in the regular white, or in the yellow.

I can furnish any of these varieties of corn at the prices printed in the big catalog, which you already have. You will be safe in ordering at these prices any time in May.

If you are in a hurry, you can telegraph or telephone your order and we will make prompt shipment, and if you are in an especially big hurry, we can send it to you by express. Of course, you must remember that you would have to pay the express charges.

If you have lost your stand of corn and have to replant, or if you have some overflow land, or something of that kind, that you can't get into until some time in June, don't get discouraged, for we can fix you out with corn that will make a crop yet.

"My spotted sow arrived safely Friday, and she sure is a dandy. Many thanks to you and $M r$. Sutliff for picking so nice one. Tuesday, March 27th, she had a litter of ten of the louliest pigs, and they sure are doing fine. Will urite again how they are doing fine.

doing later." Williarns, Strawberry Pt., Jowa. 


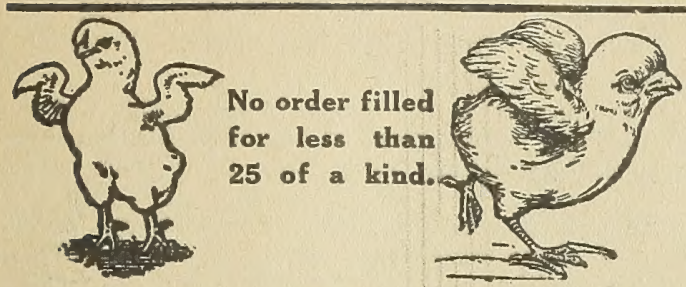

1923 Prices on Baby Chicks, Via Variety

Barred Plymouth Rocks

White Plymouth Rocks

White Wyandottes

Rose Comb Reds.

Single Comb Reds.

Single Comb Buff Orpingtons

Light Brahamas

Black Langshans

S. C. Black Minorcas -

S. C. Mottled Anconas

S. C. Buff Leghorns.

S. C. White Leghorns

S. C. Brown Leghorns

R. C. Brown Leghorns

Odds and Ends

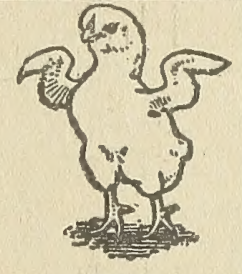

\section{5}

$\$ 5.00$

6.00

6.00

5.00

5.00

6.00

9.00

6.00

6.50

5.00

5.00

4.50

4.50

5.00

4.00

90

11.00

11.00

9.00

9.00

11.00

17.00

11.00

12.00

9.00

9.00

8.00

8.00

9.00

7.50

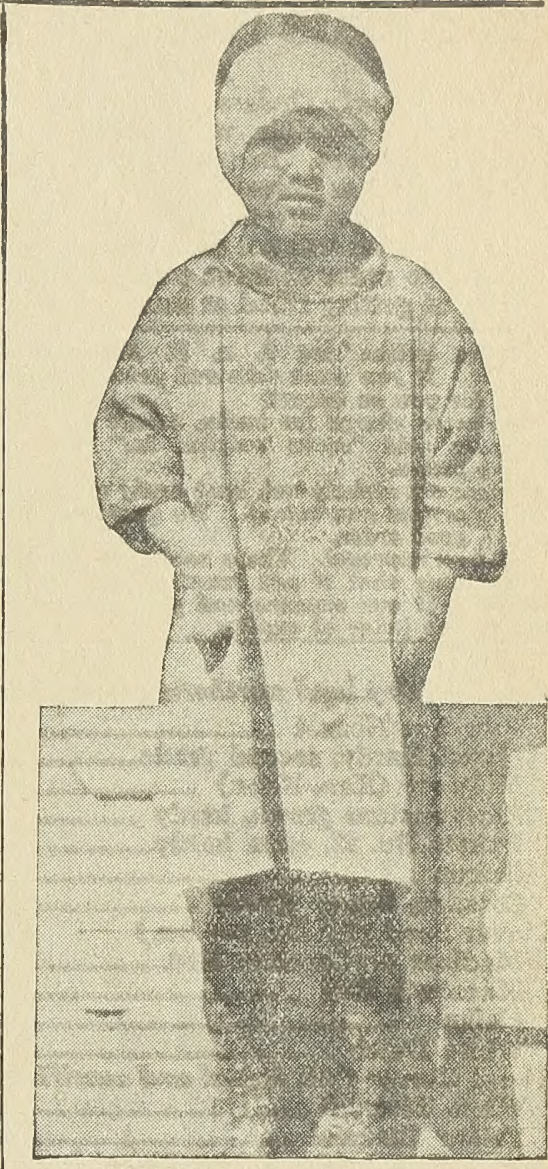

Letty Gets Bumped

Yes, this is our 4 year old, baby Letty, and the bandage is a real one. All there is to it, she got knocked down by an automobile the other day, right in front of the seed house, and she was run over and rolled and dragged, and everything else you could think of, but by the grace of a miracle, or "the Field luck," or something equally potent, she escaped with nothing else but some bad bruises.

It was the old story of a Ford driving too fast, and couldn't stop in time, and a little girl crossing the street and getting rattled.

I rushed out in the street and helped get her from under the car, and carried her to the hospital, thinking she certainly couldn't have escaped without a lot of broken bones, and you can imagine our relief when the doctors and the nurse told us there was nothing worse than bruises and nervous shock. How she came through it alive I don't see yet, but she was able to be up to breakfast the next morning.

But Letty will be shy of strange Fords for quite some time.

\section{Dala Cabbage Good}

The Dala cabbage is the best cabbage $I$ have found in my 7 years gardening. It did well last year for me. Stood the dry weather the best for this locality. -J. B. Whipple, Falls City, Nebr. 


\section{Wholesale Net Prices April 1, 1923}

\section{Address all orders to Henry Field Seed Co., Shenandoah, lowa}

We Want Early Orders-So we have made these prices very low. We have the seed in the house, bought right, and up to May 1, if possible, we will sell at these prices. When it is gone and we have to buy more at higher prices, you will have to pay more. Better buy now while the buying is good. Write for special quotations after May 1 , or send order and I will fill at lowest price.

These prices are the ones ruling at this time, April 1, and we hope to be able to continue them without change up to May 1, but we will not promise positively to do so, as there are indications of sharp advances in many lines. It will be all right to order at these prices with understanding that the re may be changes either way. Early orders are practically certain of getting filled at these prices.

These prices are f. o. b. Shenandoah, customer to pay the freight. If you want delivered prices we will make a special estimate for you on requst.

No extra charge for sacks, except for wheat and rye. All other seeds sold "sacks weighed in." Remember this when com. paring prices.

Prices are strictly net, spot cash; no discount.

Safe arrival guaranteed. We guarantee that all seeds will reach you in good order.

Sold on approval. These seeds are priced and sold with the understanding that if not found strictly satisfactory they may be returned at our expense and your money will be refunded. You can be the judge of quality

Per Equals (Dry land northern grown, hardy) 100 lbs. per bu.

Poor but Honest _.... $\$ 15.00 \$ 9.00$

Mixed Hardy, second grade___ 18.0010 .80

Midwest (Kan.-Nebr.)

Northwestern grown, hardy $27.00 \quad 16.20$

Dakota No. 12, extra hardy

Grimm

Cossack, Super Hardy

Clover Seed ( 60 lbs. per bu.)

Medium or Common Red._. 25.00

Mammoth Red

Alsike

White Dutch

65.00

Sweet Clover (All hulled and scarified)

White Biennial - 15.50

Yellow Biennial 15.50

New Grundy Co. White Biennial_..... 18.00

HUBAM (Annual White) 30.00

Timothy and Timothy Mixtures ( 45 lbs. per bu.)

Timothy, best home grown 8.00

Timothy-Alsike Mixture (20 per cent Alsike) 10.00

Timothy-Red Clover Mixture

(20 per cent Clover)

Timothy-Mammoth Mixture

(20 per cent Clover) _........... 12.00

Blue Grass

Kentucky Blue Grass_-_-_-_ 36.00

Canadian Blue Grass.....-. 32.00

English Blue Grass _._.

Other Grasses

Italian Rye Grass___._. 15.00

Perennial Rye Grass

Bromus Inermis -....... 15.00

Red Top, fancy solid seed......... 28.00

Red Top, unhulled or rough seed.......- 12.00

Orchard Grass

Bermuda Grass _...................... 38.00

5.04

4.48
Reference. First National Bank, of Shenandoah, Iowa.

Free Samples. We will gladly send free samples of any kind of seed quoted here.

Subject to Sale. All prices are subject to stock being unsold on receipt of order.

\section{YOUR MONEY'S WORTH OR YOUR MONEY BACK}

It is mutually agreed and understood that any seeds or other goods ordered of us may be returned at any time within ten days after receipt if not satisfactory, and money paid for them will be refunded, but we do not, and cannot, in any way, warrant the crop, as it is dependent on so many conditions beyond our control.

Other Grasses Cont.

Per Equals

Lawn Grass Mixture 100 lbs, per bu.

Zealand Chewings Fescue

Red Fescue _. 65.00

Permanent Pasture Mixture_._._._._._. 16.00

Permanent Meadow Mixture____.___._ 16.00

Lowland Pasture Mixture._. 16.00

45.00 SUDAN 15.00

DWARF ESSEX RAPE

15.00 SUNFLOWER SEED _.

16.20 HOG PASTURE MIXTURE

13.20 KAFFIR CORN AND MILO MAIZE__.... 5.00

39.00 FETERITA $\quad 5.00$

FODDER CANE

SYRUP CANE (Several varieties)

9.30 PULVERIZED SHEEP MAN URE _... 3.25

10.80 Soy Beans and Stock Peas ( 60 lbs. per bu.)

Soy Beans, Ito San, extra early, yellow

Soy Beans, Midwest, Improved Med. Yellow 6.00

Soy Beans, Pekin, fine for ensilage, black_- 6.00

Soy Beans, Manchu, fine main crop, yellow _- 6.00

Soy Beans, Virginia, soiling and hay, brown 6.66

Soy Beans, Columbian, hogging down and hay 6.00

Cow Peas, Whippoorwill

Cow Peas, New Era_____________. 7.00

Cow Peas, Mixed 6.50

Canadian Field Peas _... 6.00

Millet ( 50 lbs. per bu.)

Golden _. 5.00

Common or Fodder

$5.00 \quad 2.50$

Small Grain

Spring Wheat, Marquis

Buckwheat

Oats, Iowa No. 103 (White Kherson)

Barley, bearded _...- 1.25

3.50 Broadcast Seeders

Cyclone, each (allow postage for 5 lbs.)

$\$ 2.00$
Seed Corn Shelled and graded. High testing. All the leading varieties, early, medium and late.
$10 \mathrm{bu}$. lots
$\$ 2.75$ bu.
$1 \mathrm{bu}$. lots
$5 \mathrm{bu}$. lots
$\$ 2.85 \mathrm{bu}$.
$\$ 3.00 \mathrm{bu}$.
$1 / 2$ bu.
$\$ 1.75$

Fodder and Ensilage Corn

Mammoth White and Leaming, also Early Dent Fodder.
10 bu. lots
$\$ 2.00 \mathrm{bu}$.
1 bu. lots
$\$ 2.25$ bu.
5 bu. lots
$\$ 2.10 \mathrm{bu}$
$1 / 2 \mathrm{bu}$
$\$ 1.25$
2 bu. lots
$\$ 2.15$ bu.
Pk.
$.75 \mathrm{c}$

\section{DON'T NEGLECT TO INOCULATE AT PLANTING TIME}

Your Clover-Alfalfa_-Sweet Clover-Soy Beans-and Cow Pea Seed

\section{Nitragin}

(Bu. sizes instead of acre sizos)

$\begin{aligned} 1 / 4 & \text { bu. size can } \\ 1 / 2 & \text { bu. size can } \\ 1 & \text { bu. size can } \\ 5 & \text { bu. size can }\end{aligned}$

Garden size, Peas and Beans only-
Farmogorm

1 acre size -

3 acre size

12 acre size

Garden size, combination 